JURNAL ILMIAH KOMPUTER GRAFIS, Vol.14, No.2, Des 2021, pp. 315 - 322

p-ISSN : 1979-0414 (print)

e-ISSN : 2614-6256 (online)

http://journal.stekom.ac.id/index.php/E-Bisnis

\title{
Analisis Implementasi Temperature Screening Contactless berbasis Internet Of Things (IOT) Menggunakan Protokol Message Queue Telemetry Transport (MQTT)
}

\author{
Unang Achlison ${ }^{1}$, Khoirur Rozikin ${ }^{2}$, Fujiama Diapoldo Silalahi $^{3}$ \\ ${ }^{1}$ Teknik Elektronika - Universitas STEKOM, unang@stekom.ac.id \\ ${ }^{2}$ Teknik Komputer - Universitas STEKOM, khoirur@stekom.ac.id \\ ${ }^{3}$ Sistem Komputer - Universitas STEKOM, fujiama@stekom.ac.id \\ Jl. Majapahit 605, Semarang, telp/fax : 024-6717201-02
}

\section{ARTICLE INFO}

Article history:

Received

Received in revised form

Accepted

Available online

\begin{abstract}
Remote temperature monitoring is needed in hazardous area conditions or fast data retrieval is needed without being limited by distance. This condition can be overcome by monitoring and measuring the temperature from a remote location using internet technology that is currently developing, namely the Internet of things. There are many implementations of remote temperature monitoring systems, but the measurement results of these sensors sometimes have very significant differences even for measuring the temperature of the same object. This study aims to analyze the implementation of an effective and efficient remote temperature monitoring system. The temperature measurement process uses the LM35 and MLX 90614 sensors based on Internet of things technology using the Message Queue Telemetry Transport (MQTT) protocol. After obtaining the results of temperature measurements using different sensors, the measurement results are analyzed and compared with standard temperature measuring instruments to obtain an effective and efficient implementation. Based on the analysis, the results of temperature measurements using the MLX 90614 sensor are effective and efficient sensors.
\end{abstract}

Keywords: micro, sensor, temperature, Internet of things.

\footnotetext{
ABSTRAK

Monitoring suhu jarak jauh sangat dibutuhkan pada kondisi daerah yang berbahaya atau diperlukan pengambilan data yang cepat tidak terbatas jarak. Kondisi ini dapat diatasi dengan memonitor dan mengukur temperatur dari lokasi yang jauh menggunakan teknologi internet yang sedang berkembang pada saat ini yaitu Internet of thing. Banyak implementasi sistem monitoring suhu jarak jauh namun hasil ukur sensor tersebut terkadang memiliki perbedaan yang sangat signifikan meskipun untuk pengukuran suhu objek yang sama. Penelitian ini bertujuan untuk menganalisa implementasi sistem monitoring suhu jarak jauh yang efektif dan efisien. Proses pengukuran suhu menggunakan sensor LM35 dan MLX 90614 tanpa sentuh berbasis teknologi Internet of thing menggunakan protokol Message Queue Telemetry Transport (MQTT). Setelah didapatkan hasil pengukuran suhu dengan menggunakan sensor yang berbeda, hasil pengukuran tersebut dianalisis dan dibandingkan dengan alat ukur suhu standar untuk mendapatkan implementasi yang efektif dan efisien. Berdasarkan analisis, hasil pengukuran suhu menggunakan sensor MLX 90614 merupakan sensor yang efektif dan efisien.
}

Katakunci: micro, sensor, suhu, Internet of thing. 


\section{Pendahuluan}

Seiring mewabahnya virus Corona atau Covid-19 ke ratusan negara, Pemerintah Republik Indonesia menerbitkan protokol kesehatan. Protokol tersebut akan dilaksanakan di seluruh Indonesia oleh pemerintah dengan dipandu secara terpusat oleh Kementerian Kesehatan RI [1]. Pemerintah menerbitkan protokol kesehatan yang wajib diterapkan di pusat perbelanjaan, kantor, hotel, hingga pusat keramaian lainnya, salah satunya adalah pemeriksaan suhu tubuh setiap pengunjung [2]. Untuk mengurangi penyebaran dan memutus rantai Covid-19 pemerintah menerapkan kebijakan sosial distancing. Masyarakat di himbau agar tidak berkerumun dan harus menjaga jarak 1 meter dengan orang di sekitarnya [3][4]. Di dalam ruangan pun hanya dibatasi beberapa orang saja.

Monitoring suhu jarak jauh sangat bermanfaat jika dilakukan pada daerah yang luas, daerah yang berbahaya atau untuk kecepatan pengambilan data karena hanya peralatan sensor dan sistem transmisi yang berada di lokasi. Akses jarak jauh dapat melalui media kabel, nirkabel atau serat optik baik secara point to point maupun jaringan.

Perkembangan teknologi internet pada saat ini adalah Internet of Things yang merupakan layanan menghubungkan objek (things) baik fisik maupun virtual berbasis teknologi internet [5]. Salah satu solusi yang dapat digunakan adalah penggunaan Internet of Things (IoT) [6][7][8]. IoT dapat digunakan sebagai sarana pengumpulan data, dengan menggunakan beberapa protokol, diantaranya adalah HTTP, MQTT, CoAP [9]. Protokol MQTT memiliki beberapa kelebihan. Kelebihan dari protokol MQTT yaitu header lebih ringkas sehingga dapat menghemat sumber daya dan lebih ringan.

Seiring dengan kemajuan teknologi elektronika dalam bidang sistem otomasi (Automation System) memunculkan beberapa perangkat canggih yang dapat mengukur suatu parameter yaitu dengan menggunakan sensor [10]. Terdapat banyak jenis dan varian sensor yang dapat mengukur temperatur di udara, namun setiap sensor tersebut memiliki tingkat akurasi dan ketelitian yang berbeda-beda pula.

Publikasi yang terkait dengan memonitor atau mengukur suhu jarak jauh sudah ada dengan berbagai metoda baik cara transmisi jarak jauhnya maupun protokol yang digunakan. Pada artikel [11] pengiriman data suhu dilakukan point to point secara nirkabel dengan menggunakan protokol komunikasi Universal Asyncrounous Syncronous Receiver Transmitter (UASRT), yang merupakan protokol standar pengiriman data serial pada mikrokontroler. Pada artikel [12] pengiriman data suhu menggunakan saluran komunikasi seluler dengan protokol Short Message Service (SMS). Sistem ini mampu menjangkau jarak yang jauh namun masih bersifat point to point. Pada artikel [13] pengiriman data suhu menggunakan SMS dan Web yang dapat diakses melalui perangkat berbasis Android. Sistem ini juga masih bersifat point to point sehingga bila diperlukan penambahan titik sensor maka harus menduplikasi sistem.

Dalam penelitian ini akan dibahas hasil pembacaan suhu tanpa sentuh (temperature screening contactless) berbasis teknologi internet of things. Pembacaan yang dihasilkan sensor-sensor ini akan dibandingkan dengan pembacaan yang dihasilkan thermometer acuan. Dari percobaan ini dapat diketahui tingkat akurasi masing-masing sensor untuk kemudian diambil kesimpulan manakah jenis sensor dengan ketelitian paling efektif.

Implementasi pembacaan suhu tanpa sentuh (temperature screening contactless) berbasis teknologi internet of things telah banyak dilakukan oleh beberapa peneliti, antara lain sistem pemeriksa suhu tubuh dan jumlah orang berbasis IoT dengan protokol MQTT. 
JURNAL ILMIAH KOMPUTER GRAFIS, Vol.14, No.2, Des 2021, pp. 315 - 322

p-ISSN : 1979-0414 (print)

e-ISSN : 2614-6256 (online)

http://journal.stekom.ac.id/index.php/E-Bisnis

Pemeriksa suhu tubuh menggunakan NodeMCU dan memudahkan pemilik atau pengawas suatu gedung untuk mengetahui berapa jumlah orang dalam gedung, sensor ultrasonik dan sekaligus memeriksa suhu tubuh dengan sensor MLX 90614. Data jumlah orang dan suhu tubuh dikirim ke broker MQTT dari IoT platform Thingsboard yang nantinya dapat diakses melalui Web User Interface. Dengan demikian sistem ini dapat menghimpun dan mendiagnosis suhu dan jumlah orang dalam suatu gedung saat memasuki suatu gedung [14][15].

Penelitian-penelitian terdahulu terkait pengukuran suhu juga telah dilakukan antara lain implementasi teknologi berbasis IoT dengan protokol MQTT untuk sistem monitoring suhu jarak jauh. Implementasi sistem menggunakan sensor suhu LM35, Arduino UNO dan modul wifi Esp8266 ver 01. Prototype sistem berhasil direalisasikan baik pada Node Sensor maupun Node Monitor [16].

Namun dari sekian banyak rancang bangun alat yang menggunakan sensor suhu tanpa sentuh berbasis IoT dengan protokol MQTT di atas, hasil ukur sensor sehu memiliki perbedaan yang sangat signifikan meskipun untuk mengukur suhu pada objek yang sama.

Efektifitas hasil ukur berkaitan penggunaan sensor suhu berbasis IoT dengan protokol MQTT menjadi topik yang menarik untuk dilakukan analisis lebih jauh. Jenis sensor suhu menjadi penentu akurasi output pengukuran yang dihasilkan. Tujuan dari penelitian ini adalah menganalisis hasil pengukuran suhu dan kelembaban udara sebagai variabel independen terhadap variasi jenis sensor suhu dan kelembaban udara yang digunakan sebagai variabel dependen.

\section{Landasan Teori}

\section{a. Sensor Suhu LM35}

Sensor suhu LM35 adalah komponen elektronika yang memiliki fungsi untuk mengubah besaran suhu menjadi besaran listrik dalam bentuk tegangan. LM35 memiliki keakuratan tinggi dan kemudahan perancangan jika dibandingkan dengan sensor suhu yang lain, LM35 juga mempunyai keluaran impedansi yang rendah dan linieritas yang tinggi sehingga dapat dengan mudah dihubungkan dengan rangkaian kendali khusus serta tidak memerlukan penyetelan lanjutan. Tiga pin LM35 menunjukkan fungsi masingmasing pin diantaranya, pin 1 berfungsi sebagai sumber tegangan kerja dari LM35, pin 2 atau tengah digunakan sebagai tegangan keluaran atau Vout dengan jangkauan kerja dari 0 Volt sampai dengan 1,5 Volt dengan tegangan operasi sensor LM35 yang dapat digunakan antar 4 Volt sampai 30 Volt. Keluaran sensor ini akan naik sebesar $10 \mathrm{mV}$ setiap derajad celcius [17].
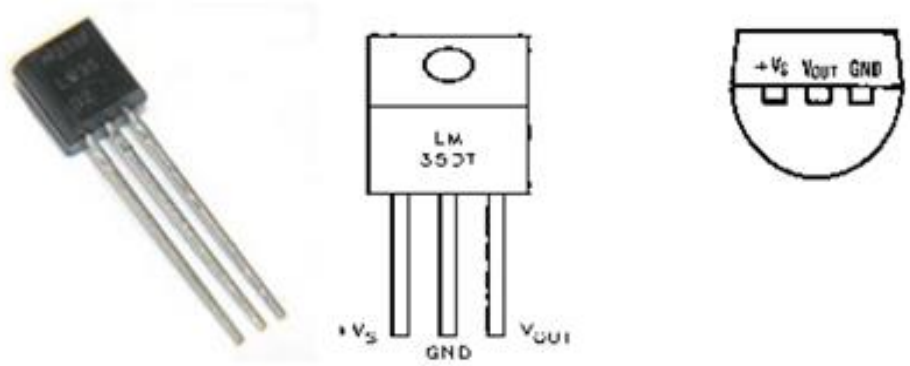

Gambar 1. Sensor Suhu LM35

(sumber http://elektrosmart22.blogspot.com/2016/11/sensor-suhu-lm35.html)

\section{b. Sensor Suhu MLX90614}


Sensor MLX90614 merupakan sensor yang digunakan untuk mengukur suhu dengan memanfaatkan radiasi gelombang inframerah. Sensor MLX90614 yang ditunjukkan pada Gambar 2 didesain khusus untuk mendeteksi energi radiasi inframerah dan secara otomotis telah didesain sehingga dapat mengkalibrasikan energi radiasi inframerah menjadi skala temperatur. MLX90614 terdiri dari detektor thermopile inframerah MLX81101 dan signal conditioning ASSP MLX90302 yang digunakan untuk memproses keluaran dari sensor inframerah. Sensor MLX90614 merupakan sensor suhu contacless, artinya untuk mengukur temperatur, sensor ini tidak perlu bersentuhan langsung dengan objek tersebut [18].

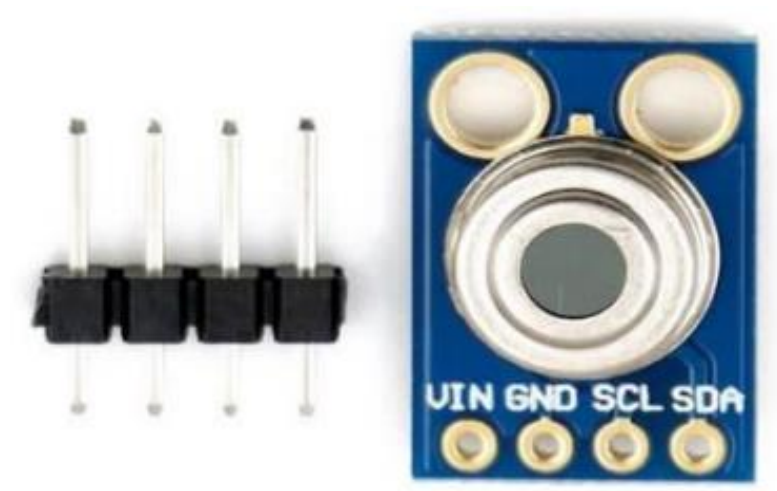

Gambar 2. Sensor MLX90614

\section{Metodologi}

Pada penelitian ini membahas tentang perbandingan nilai ukur sensor suhu tanpa sentuh berbasis teknologi internet of things dengan protokol MQTT terhadap variasi jenis sensor suhu yang digunakan yaitu sensor LM-35 dan MLX90614. Penelitian ini menggunakan pendekatan analisa perbandingan nilai hasil pengukuran yang dihasilkan dari variasi jenis sensor suhu yang digunakan dan akan ditetapkan mana yang lebih akurat dan efisien.

\subsection{Desain Penelitian}

\section{Metode Pengumpulan Data}

Metode pengumpulan data dalam penelitian ini melalui hasil pengukuran pada alat ukur suhu tanpa sentuh berbasis teknologi internet of things dengan protokol MQTT. Blok diagram adalah suatu bagian dari prinsip dan kinerja suatu sistem dalam membuat suatu perancangan alat. Cara kerja keseluruhan sebuah alat yang akan dibuat terletak pada blok diagram system. Berikut ini merupakan gambar blok diagram dari sistem kerja pengukuran sensor suhu tanpa sentuh berbasis teknologi internet of things dengan protokol MQTT.

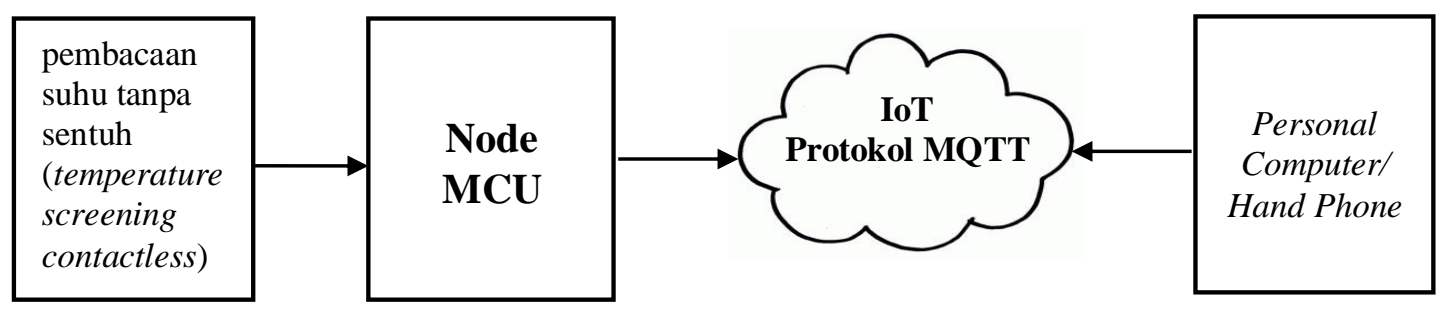

Gambar 3. Blok diagram sistem kerja pengukuran sensor suhu tanpa sentuh

Berdasakan blok diagram pada gambar 3, bagian sensor suhu sebagai inputan pendeteksi suhu udara yang akan diukur, bagian Node MCU sebagai unit pemroses dan 
JURNAL ILMIAH KOMPUTER GRAFIS, Vol.14, No.2, Des 2021, pp. 315 - 322

p-ISSN : 1979-0414 (print)

e-ISSN : 2614-6256 (online)

http://journal.stekom.ac.id/index.php/E-Bisnis

pengendali seluruh sistem alat, pengolah data digital menjadi hasil ukur. Hasil pengukuran suhu dapat diakses melalui perangkat Personal Computer / Hand Phone melalui web berbasis IoT dengan protokol MQTT.

\section{Flowchart}

NodeMCU mengkoneksikan dengan jaringan internet dan input adalah suhu yang dideteksi sensor LM35 dan MLX90614. NodeMCU memproses dan mengirimkan data ke broker MQTT HiveMQ menerima data. Broker MQTT akan mempublish data apabila ada yang mensubscribe. Thingsboard IoT platform sebagai subscriber akan menerima dan memvisualisasikan data suhu. Gambar 4 berikut merupakan Flowchart sistem kerja pengukuran sensor suhu berbasis IoT.

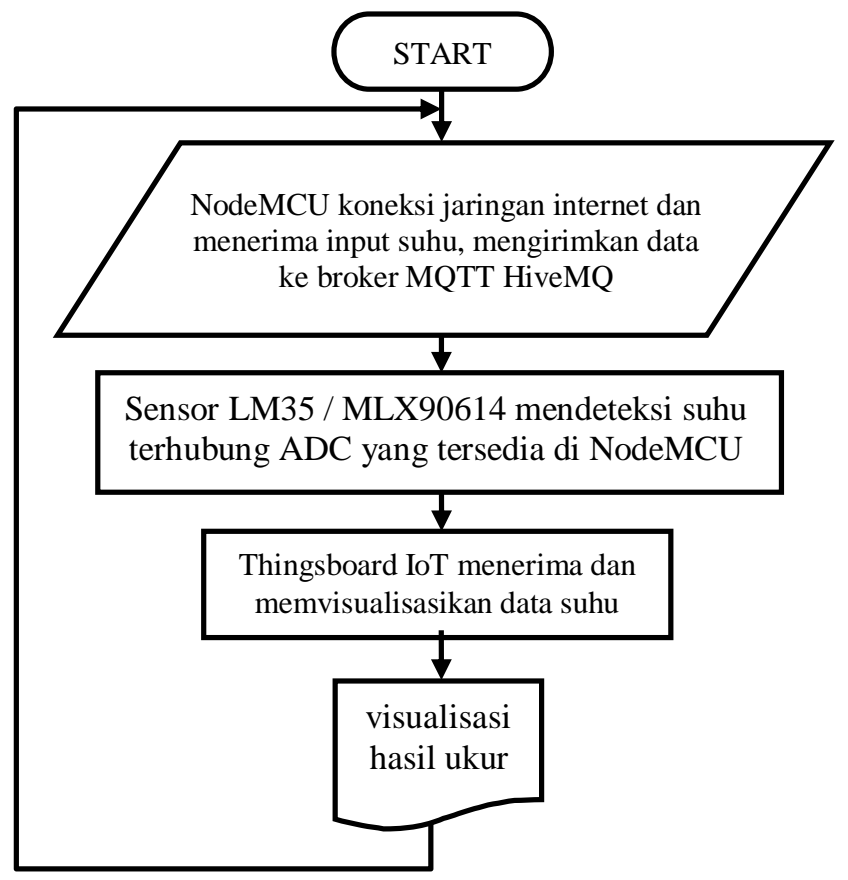

Gambar 4. Flowchart Sistem Kerja Pengukuran Suhu berbasis IoT

\section{Teknik Analisis Data}

Analisis data dilakukan untuk mengetahui ketelitian pengujian suatu alat diperlukan sebuah metode perhitungan untuk mengetahuinya. Setelah diperoleh data dari hasil pengukuran suhu oleh sensor LM35 dan MLX90614, maka langkah selanjutnya adalah menganalisa data tersebut untuk dilakukan perhitungan analisis nilai persentase (\%) keberhasilan dan nilai persentase (\%) kesalahan (error) [19] sebagai :

Persentase Rata-Rata Hasil Pengukuran sensor Suhu $=(S 1+S 2) / 2 x 100 \%$

Persentase (\%) kesalahan (error) ditentukan oleh nilai variabel S1 dan S2 adalah hasil ukur suhu udara yaitu hasil ukur sensor LM35 dan sensor MLX90614.

\section{Hasil dan Pembahasan}

\section{A. Hasil Pengukuran Sensor Suhu berbasis IoT.}

Pengujian sistem pengukuran suhu udara dilakukan dengan cara menggunakan sensor LM35 dan MLX90614. Udara dideteksi oleh sensor suhu menjadi tegangan terhubung bagian Analog to Digital (ADC) yang tersedia di Node MCU berfungsi untuk mengubah tegangan menjadi data digital. Node MCU mengolah data digital dan 
mengirim ke thingsboard IoT platform sebagai subscriber yang akan menerima dan memvisualisasikan data suhu. Hasil pengujian ditunjukkan pada Tabel sebagai berikut.

Pengujian sistem pengukuran suhu udara menggunakan sensor LM35 dan hasil pengukuran ditunjukkan pada tabel 1.

Tabel 1. Hasil Ukur Suhu Udara Menggunakan Sensor LM35

\begin{tabular}{ccccc}
\hline No & $\begin{array}{c}\text { Thermometer } \\
\text { standar }\left({ }^{\circ} \mathrm{C}\right)\end{array}$ & $\begin{array}{c}\text { Hasil Ukur Suhu } \\
\left({ }^{\circ} \mathrm{C}\right)\end{array}$ & $\begin{array}{c}\text { Selisih } \\
\left({ }^{\circ} \mathrm{C}\right)\end{array}$ & $\begin{array}{c}\text { Persentase Selisih } \\
\text { (Selisih/Nilai Standar }) \\
\text { x100\% }\end{array}$ \\
\hline 1 & 27,00 & 26,00 & 1,00 & 3,70 \\
\hline 2 & 27,20 & 26,20 & 1,00 & 3,67 \\
\hline 3 & 27,30 & 26,20 & 1,10 & 4,02 \\
\hline 4 & 27,70 & 26,54 & 1,16 & 4,18 \\
\hline 5 & 28,00 & 26,88 & 1,12 & 4,00 \\
\hline 6 & 30,00 & 29,03 & 0,97 & 3,23 \\
\hline Rata-rata & 27,74 & 26,70 & 1,05 & 3,80 \\
\hline
\end{tabular}

Sumber : Totok Budioko; 2016 [22]

Berdasarkan data pada tabel 1 dapat disimpulkan bahwa persentase selisih rata-rata suhu udara hasil ukur alat (simpangan) terhadap thermometer standar mencapai +/$3,80 \%$.

Pengujian sistem pengukuran suhu udara menggunakan sensor MLX90614 dan hasil pengukuran ditunjukkan pada tabel 2 .

Tabel 2. Hasil Ukur Suhu Udara Menggunakan Sensor MLX90614

\begin{tabular}{ccccc}
\hline No & $\begin{array}{c}\text { Thermometer } \\
\text { standar }\left({ }^{0} \mathrm{C}\right)\end{array}$ & $\begin{array}{c}\text { Hasil Ukur } \\
\left({ }^{0} \mathrm{C}\right)\end{array}$ & $\begin{array}{c}\text { Selisih } \\
\left({ }^{0} \mathrm{C}\right)\end{array}$ & $\begin{array}{c}\text { Persentase Selisih } \\
\text { (Selisih/Nilai Normal }) \\
\text { x 100\% }\end{array}$ \\
\hline 1 & 33,90 & 33,90 & 0 & 0 \\
\hline 2 & 34,70 & 34,23 & 0,47 & 1,35 \\
\hline 3 & 34,00 & 33,23 & 0,77 & 1,93 \\
\hline 5 & 34,60 & 33,93 & 1,37 & 1,96 \\
\hline 6 & 34,10 & 33,90 & 0,67 & 2,24 \\
\hline 7 & 34,60 & 34,17 & 0,43 & 0,94 \\
\hline 8 & 35,00 & 34,21 & 0,79 & 0,67 \\
\hline 10 & 35,00 & 34,67 & 0,33 & 1,43 \\
\hline Rata-rata & 34,20 & 33,97 & 0,23 & 1,40 \\
\hline Sumber & 34,20 & 33,71 & 0,49 & $14]$
\end{tabular}

Sumber : Dede Irawan Saputra, Gian Melky Karmel , Yuda Bakti Zainal, 2020 [14]

Berdasarkan data pada tabel 2 dapat disimpulkan bahwa persentase selisih rata-rata suhu udara hasil ukur alat (simpangan) terhadap thermometer standar mencapai +/$1,40 \%$. 
JURNAL ILMIAH KOMPUTER GRAFIS, Vol.14, No.2, Des 2021, pp. 315 - 322

p-ISSN : 1979-0414 (print)

e-ISSN : 2614-6256 (online)

http://journal.stekom.ac.id/index.php/E-Bisnis

\section{B. Tampilan Aplikasi untuk pelanggan (Customer)}

Berdasarkan tabel 1 dan tabel 2, maka perbedaan antara hasil ukur sensor suhu udara dapat disimpulkan seperi pada tabel 3 .

Tabel 3. Perbedaan Hasil Ukur Suhu Udara Sensor LM35 dan MLX90614.

\begin{tabular}{lcccc}
\hline $\begin{array}{c}\text { Nama } \\
\text { Sensor Suhu }\end{array}$ & $\begin{array}{c}\text { Rata-rata } \\
\text { Thermometer } \\
\left({ }^{0} \mathrm{C}\right)\end{array}$ & $\begin{array}{c}\text { Rata-rata } \\
\text { Hasil Ukur } \\
\left({ }^{\circ} \mathrm{C}\right)\end{array}$ & $\begin{array}{c}\text { Rata-rata } \\
\text { Selisih } \\
\left({ }^{\circ} \mathrm{C}\right)\end{array}$ & $\begin{array}{c}\text { Rata-rata } \\
\text { Persentase Selisih } \\
\text { (Selisih/Nilai } \\
\text { Normal) x100\% }\end{array}$ \\
\hline LM35 & 27,74 & 26,70 & 1,05 & 3,80 \\
\hline MLX90614 & 34,43 & 33,99 & 0,55 & 1,40 \\
\hline
\end{tabular}

Berdasarkan data pada tabel 3 dapat disimpulkan bahwa persentase selisih hasil ukur sensor suhu udara dapat menghasilkan hasil ukur yang mendekati hasil ukur Thermometer. Jenis sensor MLX90614 mempunyai selisih hasil ukur 1,40\% dari Thermometer sehingga lebih akurat dan efisien sebagai alat ukur suhu udara.

\section{Kesimpulan}

Berdasarkan hasil analisa data pada tabel 3, maka penulis dapat menyimpulkan penelitan ini sebagai berikut :

a. Sensor MLX90614 lebih akurat dan efisien sebagai alat ukur suhu udara.

b. Sensor MLX90614 bisa menjadi input hasil pengukuran pada alat ukur suhu tanpa sentuh yang akurat dan efisien berbasis Microcontroller NodeMCU.

c. Implementasi sensor suhu telah diuji menggunakan Microcontroller NodeMCU berbasis teknologi Internet of thing (IoT) menggunakan protokol Message Queue Telemetry Transport (MQTT).

\section{Daftar Pustaka}

[1] Dalinama Telaumbanua, "Urgensi Pembentukan Aturan Terkait Pencegahan Covid19 di Indonesia," Jurnal Pendidikan, Sosial, dan Agama., vol. 12, no. 1, hal. 59-70, 2020

[2] Husna Ni'matul Ulya, “Alternatif Strategi Penanganan Dampak Ekonomi Covid-19 Pemerintah Daerah Jawa Timur Pada Kawasan Argopolitan," Journal of Islamic Economic and Business, vol.3, no. 1, hal.80-109, 2020.

[3] Dwizka Krisnawati, dkk. "Ketahana Negara Republik Indonesia Masa Pandemik Covid-19," Jurnal Global Citizen, vol. 9, no. 1, hal. 63-70, 2020.

[4] Neneng Nurhalimah. "Upaya Bela Negara Melalui Sosial Distancing dan Lockdown Untuk Mengatasi Wabah Covid-19," 15 April 2020. [Online]. Available at SSRN: https://ssrn.com/abstract=3576405 [Accessed 24 Agustus 2020].

[5] Ni Komang Suni Astini, "Tantangan Dan Peluang Pemanfaatan Teknologi Informasi Dalam Pembelajaran Online Masa Covid-19," Jurnal Ilmu Pendidikan, vol. 3, no. 2, hal. 241-255, 2020.

[6] Handoko R. , Susanto Sambasri, Dede Irawan Saputra, Nana Heryana, Agus Purwadi, Marsudiono, "IoT Application for On-line Monitoring of $1 \mathrm{kWp}$ 
Photovoltaic System Based on NodeMCU ESP8266 and Android Application," IEEE, 2019 2nd International Conference on High Voltage Engineering and Power Systems (ICHVEPS), pp. 230-234.

[7] Handoko Rusiana Iskandar, Hermadani Hermadani, Dede Irawan Saputra, Hajiar Yuliana, "Eksperimental Uji Kekeruhan Air Berbasis Internet of Things Menggunakan Sensor DFRobot SEN0189 dan MQTT Cloud Server," Seminar Nasional Sains dan Teknologi 2019, pp. 2-9.

[8] Dede Irawan Saputra, Agus Rohmat, Asep Najmurrokhman, Zul Fakhri, "Implementation of fuzzy inference system algorithm in brooding system simulator with the concept of IoT and wireless nodes" IOP Conference Series: Materials Science and Engineering, 2019, Vol 830, No. 3, pp. 1-6

[9] Husnul Anwari, Eko Sakti Pramukantoro, M. Hannats Hanafi, "Pengembangan Iot MiddlewareBerbasis Event-Based dengan Protokol Komunikasi CoAP, MQTT dan Websocket," Jurnal Pengembangan Teknologi Informasi dan Ilmu Komputer, vol. 1, no. 12, hlm. 1560-1567, Desember 2017.

[10] Chattoraj, S. (2015) 'Smart Home Automation based on different sensors and Arduino as the master controller', International Journal of Scientific and Research Publications, 5(1), pp. 1-4. Available at: www.ijsrp.org.

[11] Shafiudin S, , Rohma. F.J., Prasetya A.E. Firmansyah R. Pemantau Ruang Inkubator Penetasan Telur Ayam dengan Berbasis Telemetri Menggunakan Arduino UNO R3. Jurnal Nasional Teknik Elektro, 2016:27-35.

[12] Astria F, Subito M, Nugraha D.W. Rancang Bangun Alat Ukur PH dan Suhu Berbasis Short Message Service (SMS) Gateway. Jurnal MEKTRIK. 2014; 1(1):47-55.

[13] Atmoko R.A. Sistem Monitoring dan Pengendalian Suhu dan Kelembaban Ruang pada Rumah Walet Berbasis Android, Web, dan SMS, Seminar Nasional Teknologi Informasi \& Komunikasi Terapan. Semarang. 2013:283-290.

[14] Wahyu Oktavia, Nur Hayati, "Pola Karakteristik Ragam Bahasa Istilah Padamasa Pandemi Covid 19 (Corona Virus Disease 2019)," Jurnal Bahasa, Sastra, dan Pengajarannya, vol. 1, no. 1, hal.1-15, 2020.

[15] Agung Nurrahman. "Peran Pemerintah Daerah dalam Memelihara Ketenteraman dan Keterlibatan Umum (Studi Pada Penanganan Penyebaran Virus Covid-19 Di Provinsi DKI Jakarta)", Jurnal Tatapamong, vol. 2, no. 1, hal. 1-16, Maret 2020

[16] Totok Budioko. (2016). Sistem Monitoring Suhu Jarak Jauh Berbasis Internet Of Things Menggunakan Protokol Mqtt. Seminar Riset Teknologi Informasi (SRITI) tahun 2016. P353-358.

[17] Shatomedia., (2008). Sensor Suhu LM35. http://shatomedia.com /2008/12/sensorsuhu-lm35/. Tanggal akses: 05-11-2010.

[18] Dede Irawan Saputra, Gian Melky Karmel, Yuda Bakti Zainal. (2020). "Perancangan dan Implementasi Rapid Temperature Screening Contactless dan Jumlah Orang Berbasis IoT dengan Protokol MQTT". Journal Of Energy And Electrical Engineering (JEEE). Vol. 02, No. 01, Oktober, 2020

[19] PALERI, E. (2015). Aplikasi Sensor Load Cell Yzc-133 Sebagai Pendeteksi Berat Santan Pada Coconut Milk Auto Machine (other). Politeknik Negeri Sriwijaya. 